\title{
Respon Glomerulus Ren Mencit (Mus musculus L.) terhadap Pemberian Senyawa Antifertilitas dari Ekstrak Air Biji Pepaya (Carica papaya L.)
}

\section{Ren Glomerular Response of Mice (Mus musculus L.) to Antifertility Compounds from Papaya Seed Water Extract (Carica papaya L.)}

\author{
Anggi Widyaningsih ${ }^{1}$, Agung Janiks Sitasiwi ${ }^{2 *}$, Siti Muflichatun Mardiati ${ }^{2}$ \\ ${ }^{1}$ Mahasiswa Program Studi Biologi, Departemen Biologi, Fakultas Sains dan Matematika, Universitas \\ Diponegoro \\ ${ }^{2}$ Departemen Biologi, Fakultas Sains dan Matematika, Universitas Diponegoro \\ Jl. Prof. Soedarto, SH, Tembalang, Semarang \\ *Email: agssiwi@yahoo.co.id
}

Diterima 24 September 2018 / Disetujui 6 November 2018

\begin{abstract}
ABSTRAK
Penelitian ini bertujuan untuk menganalisis respon glomerulus ren mencit ( $M$. musculus) terhadap pemberian senyawa antifertilitas dari esktrak air biji pepaya (Carica papaya L.). Penelitian ini merupakan penelitian eksperimental yang dibagi dalam 5 kelompok perlakuan dengan 3 ulangan. $\mathrm{K}(-)$ bahan uji berupa akuades, $\mathrm{K}(+)$ bahan uji berupa pil kontrasepsi dosis $0.2 \mathrm{mg} / \mathrm{ml}$, P1 sampai P3 berupa bahan uji ekstrak air biji pepaya dosis masing-masing 1.4; 3.5; dan $7 \mathrm{mg} / \mathrm{ml}$. Perlakuan diberikan secara oral selama 21 hari. Pengambilan sampel dilakukan dengan cara dislokasi leher setelah paparan bahan uji berakhir. Ren diisolasi dengan cara membedah dari abdomen bagian bawah. Ren selanjutnya, ditimbang dan dibuat sediaan histologis dengan pewarnaan HE dan tebal sayatan 8 mikron. Pengukuran diameter dilakukan pada setiap sayatan, masingmasing dengan 5 bidang pandang. Hasil penelitian dianalisa dengan menggunakan Analysis of Variance (ANOVA) pada taraf kepercayaan 95\%. Hasil analisis berat ren kelompok perlakuan menunjukkan tidak berbeda bermakna $(p>0.05)$ dengan kelompok kontrol. Diameter glomerulus kelompok perlakuan menunjukkan perbedaan bermakna $(\mathrm{p}<0.05)$ dari kelompok kontrol. Kesimpulan penelitian ini adalah paparan ekstrak air biji pepaya selama 21 hari berpotensi menyebabkan kerusakan ren, ditunjukkan dengan peningkatan ukuran diameter glomerulus.
\end{abstract}

Kata kunci: Carica papaya, berat ren, diameter glomerulus

\section{ABSTRACT}

The aim of this study aims was to analyze the response of glomerular ren mice (M. musculus) to the administration of anti-fertility compound from papaya seed extract (Carica papaya L.). This study was an experimental study divided into 5 treatment groups with 3 replications. $\mathrm{K}(-)$ test material in the form of aquadest, $\mathrm{K}(+)$ test material in the form of contraceptive pill $0.2 \mathrm{mg} /$ animal/day, P1 to P3 in the form of papaya seed extract test with dose respectively $1.4 ; 3.5$; And $7 \mathrm{mg} / \mathrm{mL}$. Treatment is administered orally for 21 consecutive days. Sampling was done by dislocation of the neck after exposure of the test material is over. Ren is isolated by dissecting from the lower abdomen. Furthermore, the ren weighed and made histological preparations with HE staining and a thickness of 8 microns. The diameter measurements were performed on each section, with 5 fields of view respectively. The results were analyzed by using Analysis of Variance (ANOVA) at 95\% confidence level. The result of renal weight analysis showed that there is no significant difference $(p>0.05)$ between the treated group and with the control group. The glomerular diameter of the treatment group showed significant differences $(\mathrm{p}<0.05)$ compare the control group. The conclusion of this research is exposure of papaya seed extract for 21 days resulting in ren damage which indicated by increasing the size of glomerular diameter.

Keywords: Carica papaya, ren weight, glomerular diameter 


\section{PENDAHULUAN}

Biji pepaya secara tradisional dapat dimanfaatkan sebagai obat kontrasepsi pria, diare dan sebagai sumber untuk mendapatkan minyak dengan kandungan asam-asam lemak tertentu. Penelitian Raji et al., (2005) membuktikan bahwa ekstrak biji pepaya menyebabkan penurunan jumlah anak tikus. Udoh et al. (2005) menjelaskan bahwa ekstrak biji pepaya mempengaruhi aksis hipofisis-hipothalamus sehingga mampu mempengaruhi fungi reproduksi tikus Wistar. Mekanisme efek kerja senyawa antifertilitas pada spermatozoa pada mencit jantan ditunjukkan dengan mengecilnya volume nukleus dan sitoplasma dari sel-sel Sertoli yang menyebabkan degenerasi nukleus pada spermatosit dan spermatid sehingga proses spermatogenesis terganggu (Manivannan, 2009). Uche-Nwachi (2011) membuktikan bahwa ekstrak biji pepaya memiliki kemampuan untuk menekan proses spermatogenesis. Hasil penelitian Kristiana (2011) menunjukkan esktrak biji pepaya bangkok menyebabkan penurunan fertilitas mencit $\mathrm{BALB} / \mathrm{c}$. Punitha et al. (2015) menyatakan tikus betina diberikan kombinasi bulir buah pepaya dan ekstrak biji pepaya menunjukkan gangguan epitel endometrium, lipatan endometrium terganggu, menyusut dan terjadi pengurangan jumlah kelenjar uterus. Sitasiwi dan Mardiati (2016) membuktikan bahwa paparan senyawa antifertilitas dalam biji pepaya terbukti mempengaruhi keteraturan siklus estrus.

Biji pepaya, selain mengandung asam-asam lemak, juga diketahui mengandung senyawa kimia lain seperti golongan alkaloid, tanin dan saponin (Warisno, 2003; Sukadana dkk., 2008). Setyowati dkk. (2015) menyatakan bahwa senyawa yang terkandung dalam biji pepaya yang memiliki aksi antifertilitas adalah golongan saponin, tanin, flavonoid, terpenoid, alkaloid, sterol serta triterpene. Naggayi et al. (2015) menjelaskan pada biji pepaya terdapat beberapa senyawa yang larut dalam air, yaitu saponin, tanin, terpenoid, alkaloid, glikosida, protein, vitamin, steroid dan flavonoid.

Francis et al. (2002) menjelaskan bahwa saponin merupakan suatu glikosida alamiah yang terikat dengan steroid atau triterpena, terdiri dari gugus sapogenin. Sapogenin memiliki sifat amfifilik (surfactant properties) sehingga dapat merusak membran sel. Hal tersebut dikarenakan senyawa saponin dapat berikatan dengan gugus lipida dari membran sel sehingga mengakibatkan permeabilitas membran sel terganggu.

Astuti dkk. (2000) menjelaskan bahwa alkaloid merupakan golongan senyawa organik yang memiliki gugus atom nitrogen yang bersifat basa. Akumulasi alkaloid yang berlebih dalam tubuh dapat mengakibatkan keracunan. Kumala (2006) menyatakan bahwa kandungan nitrogen yang ada dalam senyawa alkaloid dapat mengganggu fungsi sel.

Senyawa tanin menurut Setyowati dkk. (2015) merupakan metabolit sekunder yang dapat menghambat pertumbuhan tumor. Deaville et al. (2010) menyatakan tanin merupakan senyawa kimia yang tergolong dalam senyawa polifenol serta mempunyai kemampuan mengendapkan protein. Ismarani (2012) menjelaskan senyawa tanin adalah senyawa astringent yang dapat mengikat dan mengendapkan atau menyusutkan protein. Senyawa tanin dapat mengakibatkan permeabilitas membran sel terganggu. Permeabilitas membran yang rendah akan mengakibatkan sel bengkak dan lisis. Tanin juga dapat menyebabkan iritasi pada organ ren, intestinum dan kerusakan hepar.

Guyton (2007) menjelaskan ren merupakan organ tubuh yang vital. Price and Wilson (2006) menyatakan ren merupakan organ yang rentan terhadap efek toksik, karena ren menerima 25\% dari cardiac output sehingga mudah kontak dengan zat kimia dalam jumlah besar. Proses ekskresi sisa-sisa metabolit di ren dapat menyebabkan kerusakan jaringan karena keracunan akibat kontak dengan bahan-bahan tersebut. Suhita dkk. (2013) menyatakan bahwa penggunaan obat tradisional dengan dosis serta interval waktu pemberian tertentu dapat memberikan efek atau indikasi yang berbeda pada organ, diantaranya yaitu ren.

Price and Wilson (2006) menyatakan bentuk kerusakan pada ren terlihat dengan adanya penyempitan pada ruang Bowman yang disebabkan terjadinya peradangan glomelurus ataupun poliferasi dari epitel kapsula Bowman. 
Rianita (2015) menjelaskan bahwa perubahan yang terjadi pada glomerulus dan kapsula akan mengakibatkan terganggunya fungsi produksi filtrat dan kontrol komposisi filtrat. Soekamto (2003) menyatakan adanya poliferasi glomerulus yang berasal dari pembengkakan serta penambahan sel-sel endotel dan kapiler, menyebabkan perubahan pada korpuskulum renalis secara keseluruhan, meliputi diameter glomerulus, ruang Bowman dan diameter kapsula Bowman. Perubahan struktur ren yang menyolok ketika terkena paparan senyawa toksik yaitu ditandai dengan membran glomerulus menjadi menebal, yang disebabkan dengan adanya poliferasi sel, sel membesar dan mengalami perubahan pada tubulus ren (Dewi dkk., 2013). Berdasarkan uraian tersebut, jika membran glomerulus mengalami penebalan maka dapat dikatakan bahwa diameternya dapat berubah, sehingga struktur ren sudah tidak normal lagi. Penelitian ini dilakukan dengan tujuan mengukur perubahan diameter glomerulus ren mencit sebagai respon terhadap senyawa antifertilitas dalam biji pepaya. Hasil penelitian ini diharapkan dapat dijadikan sumber rujukan awal tingkat keamanan pemakaian biji pepaya sebagai bahan pengatur fertilitas pada manusia.

\section{METODE PENELITIAN}

\section{Hewan Uji}

Penelitian tentang pengaruh perlakuan ekstrak air biji pepaya terhadap diameter glomerulus mencit (Mus musculus) dilakukan selama 3 bulan di Laboratorium Biologi Struktur dan Fungsi Hewan, Departemen Biologi, FSMUNDIP. Hewan uji yang digunakan adalah mencit (Mus musculus L.) galur Swiss Webster betina dewasa, berumur 2.5-3 bulan, dengan berat 25-30 gram. Mencit diaklimatisasi pada kondisi laboratorium selama 2 minggu. Temperatur dan kelembaban laboratorium selama pemeliharaan dalam kondisi terkontrol.

\section{Pembuatan esktrak air biji pepaya}

Bahan uji berupa biji pepaya yang dikumpulkan dari tanaman pepaya yang ditanam di daerah Semarang selatan. Biji yang telah terkumpul dicuci bersih dengan air mengalir. Biji pepaya yang telah bersih kemudian dikeringkan menggunakan oven dengan suhu $40{ }^{\circ} \mathrm{C}$. Biji yang telah kering selanjutnya dihaluskan dan diayak menjadi tepung. Tepung biji pepaya selanjutnya ditakar sesuai dengan dosis yang ditentukan kemudian dilarutkan menggunakan air mendidih. Pemberian bahan uji dilakukan saat air seduhan biji pepaya telah mencapai suhu ruang. Pembuatan ekstrak air biji pepaya dilakukan berdasar metode Adeneye dan Olagunju (2009).

\section{Pemberian Bahan Uji}

Hewan uji selanjutnya dipisahkan berdasar kelompok perlakuan dengan cara pengundian, masing-masing dengan kepadatan 3 ekor hewan per kandang. Pemberian pakan dan minum dilakukan secara ad libitum. Pakan yang diberikan adalah pakan standard dengan kode 594. Pemeliharaan hewan uji dilakukan sesuai metode Sitasiwi dan Djaelani (2011).

Paparan bahan uji diawali dengan mengelempokkan hewan uji menjadi 5 kelompok perlakuan, yaitu $\mathrm{K}(-), \mathrm{K}(+), \mathrm{P} 1, \mathrm{P} 2$, dan $\mathrm{P}$ 3. Hewan uji kelompok kontrol negatif (K-) diberi akuades; kelompok kontrol positif $\mathrm{K}(+)$ diberi pil kontrasepsi merk ' $\mathrm{X}$ ' dengan kandungan ethinylestradiol $0.03 \mathrm{mg}$ dan levonorgestrel 0.15 mg sesuai dosis harian untuk manusia; kelompok P1, P2 dan P3 diberi bahan uji dengan dosis secara berurutan 1.4, 3.5 dan $7 \mathrm{mg} /$ ekor/hari. Pemberian bahan uji dilakukan secara oral menggunakan jarum gavage pada sore hari, selama 21 hari berturut-turut.

\section{Pengumpulan Data}

Bobot badan hewan uji diukur setiap satu minggu sekali, sampai sebelum hewan uji dikorbankan. Konsumsi pakan dan minum diukur setiap hari. Hewan uji dikorbankan pada akhir perlakuan dengan cara dislokasi leher. Selanjutnya dilakukan pembedahan dari bagian bawah abdomen dan dilakukan isolasi ren kanan dan kiri. Ren yang telah diisolasi selanjutnya dibersihkan dari jaringan yang melekat, dicuci dengan menggunakan garam fisiologis dan segera ditimbang. Ren kanan yang telah ditimbang difiksasi dengan $B N F$ selama satu malam dan 
dilakukan pembuatan sediaan histologis dengan metode paraffin, ketebalan sayatan $8 \mu$ dan pewarnaan HE. Penentuan diameter glomerulus dilakukan pada 6 sayatan, masing-masing dengan 3 bidang pandang. Ukuran glomerulus yang diperoleh merupakan rataan dari diameter glomerulus dengan jarak diameter yang terjauh dengan yang terdekat.

\section{Analisis Data}

Data yang diperoleh dianalisa dengan analisis varian (ANOVA). Perbedaan antar perlakuan diuji dengan Duncan Test. Penentuan perbedaan dilakukan pada tingkat kepercayaan 5\% $(\mathrm{p}<0.05)$.

\section{HASIL DAN PEMBAHASAN}

Hasil analisis rata-rata berat badan, berat ren dan diameter glomerulus dari penelitian yang berjudul "Respon Glomerulus Ren Mencit (Mus musculus L.) terhadap Pemberian Senyawa Antifertilitas dari Ekstrak Air Biji Pepaya (Carica papaya L.)" disajikan pada Tabel 1. Data hasil ANOVA menunjukkan bahwa berat badan dan bobot ren mencit kelompok kontrol maupun kelompok perlakuan bahan uji menunjukkan berbeda tidak nyata $(p>0,05)$. Hasil analisis tersebut menunjukkan bahwa bahan uji yang diberikan tidak memberikan pengaruh yang signifikan terhadap berat badan maupun bobot ren mencit. Rerata berat badan mencit yang paling tinggi ditunjukkan pada kelompok perlakuan ekstrak air biji pepaya dosis $1,4 \mathrm{mg} / 0,5 \mathrm{ml}$ (27.77 \pm 3.10$)$, diikuti kelompok perlakuan ekstrak air biji pepaya dosis $3,5 \mathrm{mg} / 0,5 \mathrm{ml}(26.67 \pm 0.85)$, selanjutnya kelompok perlakuan pil kontrasepsi dosis $0,2 \mathrm{mg} / 0,5 \mathrm{ml}$ dengan rata-rata $26.53 \pm 2.32$, serta kelompok perlakuan ekstrak air biji pepaya dosis $7 \mathrm{mg} / 0,5 \mathrm{ml}(26.43 \pm 1.50)$ dan berat badan terendah yaitu kelompok perlakuan akuades berkisar $25.15 \pm 0.45$.

Tabel 1. Hasil analisis rata-rata berat badan, berat ren dan diameter glomerulus mencit (Mus musculus L.) setelah pemberian senyawa antifertilitas dari ekstrak air biji pepaya (Carica papaya L.).

\begin{tabular}{cccccc}
\hline & \multicolumn{5}{c}{ Perlakuan } \\
\cline { 2 - 6 } Variabel & $\mathrm{K}(-)$ & $\mathrm{K}(+)$ & $\mathrm{P} 1$ & $\mathrm{P} 2$ & $\mathrm{P} 3$ \\
& $\dot{\mathrm{X}} \pm \mathrm{SD}$ & $\dot{\mathrm{X}} \pm \mathrm{SD}$ & $\dot{\mathrm{X}} \pm \mathrm{SD}$ & $\dot{\mathrm{X}} \pm \mathrm{SD}$ & $\dot{\mathrm{X}} \pm \mathrm{SD}$ \\
\hline Berat Badan $(\mathrm{gr})$ & $25.15^{\mathrm{a}} \pm 0.45$ & $26.53^{\mathrm{a}} \pm 2.32$ & $27.77^{\mathrm{a}} \pm 3.10$ & $26.67^{\mathrm{a}} \pm 0.85$ & $26.43^{\mathrm{a}} \pm 1.50$ \\
Berat Ren $(\mathrm{mg})$ & $358.8^{\mathrm{a}} \pm 31.3$ & $369.03^{\mathrm{a}} \pm 12.4$ & $340.23^{\mathrm{a}} \pm 73.5$ & $342.26^{\mathrm{a}} \pm 58.7$ & $337.53^{\mathrm{a}} \pm 37.9$ \\
Diameter & $165.62^{\mathrm{a}} \pm 43.4$ & $360.2^{\mathrm{b}} \pm 38.8$ & $350.3^{\mathrm{b}} \pm 21.3$ & $347.24^{\mathrm{b}} \pm 6.2$ & $362.9^{\mathrm{b}} \pm 17.1$ \\
Glomerulus $(\mu \mathrm{m})$ & & & &
\end{tabular}

Keterangan: Angka yang diikuti dengan superskrip yang sama pada baris yang sama menunjukan perbedaan tidak nyata $(\mathrm{p}>0,05)$.

$\mathrm{K}(-)$ : kelompok kontrol negatif

$\mathrm{K}(+)$ : kelompok kontrol positif

$\mathrm{P}(1)$ : kelompok perlakuan bahan uji konsentrasi $1,4 \mathrm{mg} / 0,5 \mathrm{ml}$

$\mathrm{P}$ (2): kelompok perlakuan bahan uji konsentrasi 3,5 mg/0,5 ml

$\mathrm{P}$ (3): kelompok perlakuan bahan uji konsentrasi $7 \mathrm{mg} / 0,5 \mathrm{ml}$

Rerata berat badan mencit seluruh kelompok uji masih dalam kriteria yang normal. Akbar (2010) menyatakan mencit betina dengan umur 3560 hari memiliki kisaran berat badan 18-35 gr. Berdasarkan hasil analisis data berat badan mencit dapat diketahui bahwa pemberian ekstrak air biji pepaya dengan paparan selama 21 hari tidak mengakibatkan penambahan berat badan yang signifikan. Hasil penelitian ini diperkuat dengan penelitian Sibiruan dkk. (2008) yang menjelaskan bahwa pemberian ekstrak biji pepaya pada mencit betina selama 10 hari dalam tahap prakopulasi dengan dosis $10 \mathrm{mg} / \mathrm{kg} \mathrm{BB}, 50 \mathrm{mg} / \mathrm{kg}$ BB dan 75 $\mathrm{mg} / \mathrm{kg}$ BB menunjukkan paparan tersebut tidak berpengaruh nyata terhadap berat badan. Lohiya $e t$ al. (2000) menyatakan dalam hasil penelitiannya bahwa pemberian ekstrak biji pepaya pada kelinci jantan selama 35 hari tidak mengakibatkan 
penambahan berat badan yang signifikan. Berdasarkan analisis data rerata konsumsi pakan dalam penelitian Mardiati dan Sitasiwi (2016) menunjukkan bahwa bobot badan mencit pada kelompok perlakuan tidak terdapat perbedaan yang nyata dengan kelompok kontrol. Hasill penelitian menunjukkan tidak ada perbedaan bobot badan yan signifikan sehingga dapat diartikan bahwa ekstrak biji pepaya memiliki efek estrogenik yang rendah sehingga tidak menyebabkan retensi air dan penimbunan lemak subkutan yang menyebabkan peningkatan bobot badan (Hartanto, 2004).

Hasil analisis rerata berat ren mencit pada semua perlakuan menunjukkan bahwa pemberian bahan uji tidak mengakibatkan penambahan massa organ. Beberapa faktor yang diduga mempengaruhi berat ren antara lain jumlah glomerulus, adanya degenerasi lemak dan degenerasi hidropis. Santosa (2011) menyatakan perubahan bobot organ disebabkan karena adanya perubahan keadaan sel. Price and Wilson (2006) menjelaskan bahwa sel yang mengalami gangguan karena adanya senyawa asing yang masuk dapat menyebabkan kehilangan pengaturan volume pada bagian-bagian sel. Hal apa pun yang mengganggu metabolisme energi dalam sel atau melukai membran sel, maka membuat sel tersebut tidak mampu memompa ion natrium sehingga ukuran sel akan berubah. Faktor lain yang dapat menyebabkan perubahan ukuran sel adalah adanya timbunan lipid dalam sel, akibatnya sel mengalami pembengkakan.

Hasil analisis data diameter glomerulus ren mencit menggunakan uji ANOVA yang dilanjutkan uji DUNCAN dengan taraf signifikan $5 \%$, hasil analisis data diameter glomerulus tersebut menunjukkan hasil perlakuan $\mathrm{K}(-)$ berbeda nyata terhadap perlakuan $\mathrm{K}(+)$ dan perlakuan bahan uji (P1, P2 dan P3). Diameter paling lebar terlihat pada kelompok perlakuan yang menggunakan ekstrak air biji pepaya dosis 7 $\mathrm{mg} / 0,5 \mathrm{ml}$ yaitu $362,9 \pm 17,1$, selanjutnya diikuti kelompok perlakuan menggunakan pil kontrasepsi dosis $0,2 \mathrm{mg} / 0,5 \mathrm{ml}$ dengan rerata 360,2 $\pm 38,8$, kemudian kelompok perlakuan menggunakan ekstrak air biji pepaya dosis $1,4 \mathrm{mg} / 0,5 \mathrm{ml}$ yaitu $350,3 \pm 21,3$ ) serta kelompok perlakuan yang menggunakan ekstrak air biji pepaya dosis 3,5 $\mathrm{mg} / 0,5 \mathrm{ml}$ dengan rerata $347,24 \pm 6,2$ dan paling rendah pada kelompok perlakuan dengan aquades sebesar 165,62 $\pm 43,4$. Hal tersebut menunjukkan bahwa dari perlakuan ekstrak biji pepaya dosis 1,4 $\mathrm{mg} / 0.5 \mathrm{ml}$ sampai dengan dosis $7 \mathrm{mg} / 0.5 \mathrm{ml}$ memiliki potensi yang sama seperti kelompok perlakuan dengan pil kontrasepsi dosis $0.2 \mathrm{mg} / 0.5$ ml. Struktur glomerulus ren mencit setelah paparan bahan uji selama 21 hari ditampilkan pada Gambar 1.

Hasil analisis diameter glomerulus ren menunjukkan perbedaan yang nyata. Hal tersebut berbeda dengan hasil pengukuran bobot ren. Perbedaan hasil ini kemungkinan disebabkan karena glomerulus menunjukkan respon yang reversible sehingga tidak menyebabkan kenaikan bobot ren. Dewi dkk. (2013) menjelaskan bahwa perubahan makroskopis dan mikroskopis ren dapat disebabkan oleh adanya penambahan sel-sel lemak, protein maupun air. Data berat ren menunjukkan perbedaan yang tidak nyata pada semua perlakuan, hal tersebut berarti bahan uji tidak menyebabkan adanya proses degenerasi lemak, degenerasi hidropis maupun degenerasi protein di dalam ren. Hasil penelitian Nurasri (2016) menyatakan influks air ke dalam sel ren yang diakibatkan kerusakan sel merupakan faktor yang menyebabkan peningkatan massa organ ren. Kerusakan sel dapat menyebabkan terjadinya ketidakseimbangan cairan di dalam dan diluar sel sehingga menimbulkan terjadinya pembengkakan.

Berdasarkan foromikrograf glomerulus terlihat adanya peningkatan ukuran diameter glomerulus. Peningkatan ukuran diameter glomerulus yang terjadi dalam kelompok perlakuan penelitian ini dimungkinkan merupakan salah satu gejala awal terjadinya kerusakan sel. Peningkatan diameter glomerulus pada kelompok perlakuan pil kontrasepsi dosis $0.2 \mathrm{mg} / 0.5 \mathrm{ml}$, serta kelompok perlakuan ekstrak air biji pepaya dosis $1.4 \mathrm{mg} / 0.5 \mathrm{ml}$ sampai dosis $7 \mathrm{mg} / 0.5 \mathrm{ml}$ dibandingkan kelompok perlakuan aquades diduga disebabkan karena senyawa antifertilitas pada dosis tersebut mengganggu struktur ren yang ditandai dengan terjadinya pembengkakan pada glomerulus.

Hasil analisis data diameter glomerulus menunjukkan bahwa tidak terdapat perbedaan 
yang nyata antara kelompok perlakuan pil kontrasepsi dosis $0.2 \mathrm{mg} / 0.5 \mathrm{ml}$, serta kelompok perlakuan ekstrak air biji pepaya dosis $1.4 \mathrm{mg} / 0.5$ $\mathrm{ml}$ sampai dosis $7 \mathrm{mg} / 0.5 \mathrm{ml}$, sehingga diduga potensi yang dimiliki senyawa antifertilitas dalam ekstrak air biji pepaya setara dengan pil kontrasepsi. Senyawa dari ekstrak air biji pepaya yang diduga berperan dalam peningkatan diameter glomerulus ren mencit yaitu senyawa estrogenik atau androgenik yang kemungkinan mekanisme aksinya sama seperti pil kontrasepsi.
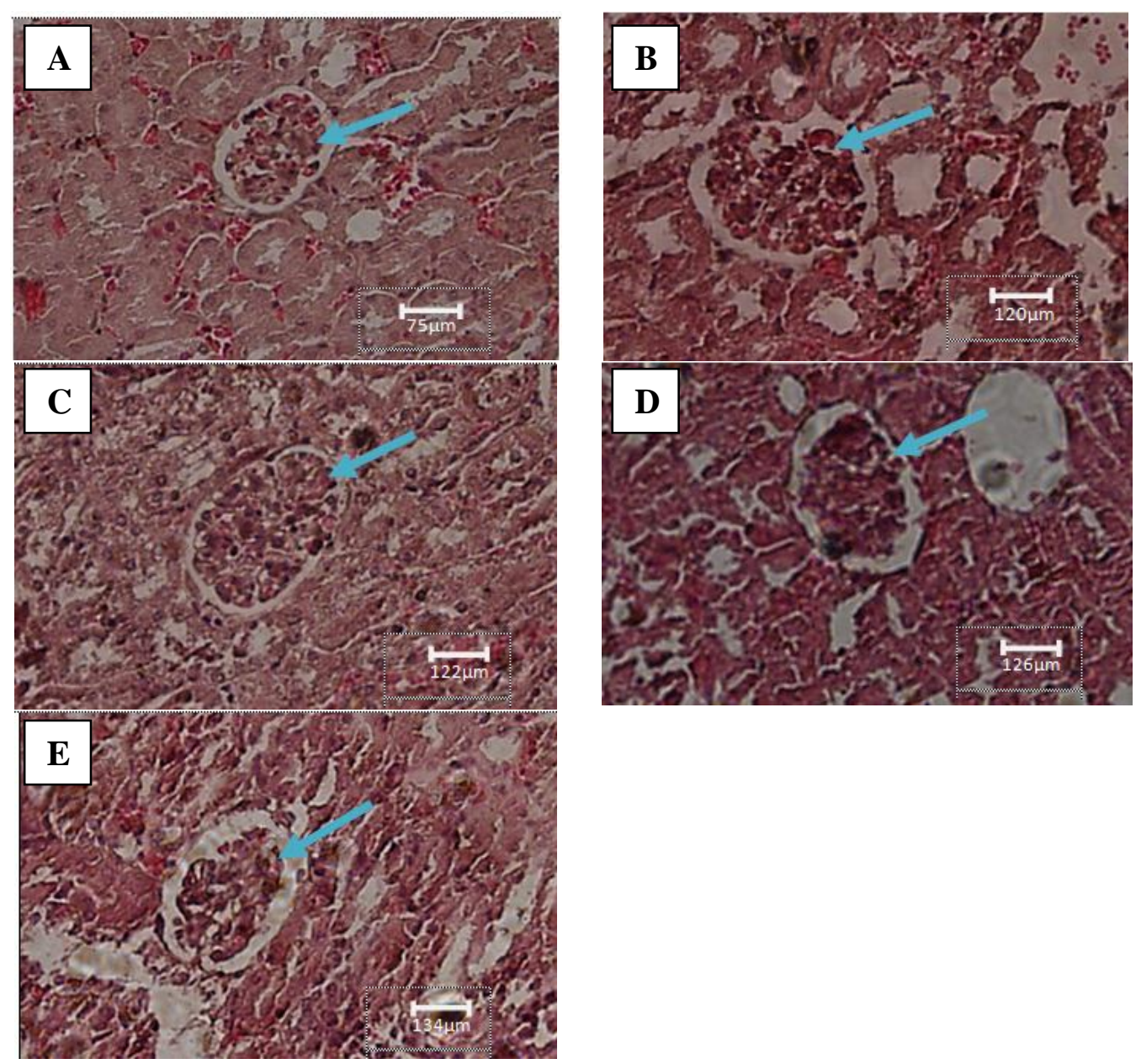

Gambar 1. Fotomikrograf ren mencit dengan pewarnaan HE (Perbesaran 20 x 10).

Keterangan: (A) Glomerulus kelompok K(-), (B) Glomerulus kelompok K(+), (C), (D), (E) Fotomikrograf ren mencit kelompok P1, P2 dan P3.

Ekstrak biji pepaya diduga mengandung beberapa senyawa yang berpotensi sebagai bahan antifertilitas alami. Astuti dkk. (2000) menyatakan senyawa tanaman obat yang berpotensi sebagai antifertilitas, umumnya berasal dari golongan flavonoid, steroid, triterpenoid, alkaloid, tanin dan saponin. Kurnijasanti dkk., (2008) menjelaskan saponin merupakan senyawa aktif yang mempunyai sifat antiestrogen yang juga memiliki efek anti inflamasi dan bersifat sitotoksik. Bottger et al. (2012) menyatakan saponin mampu berinteraksi dengan permukaan fisik seperti membran sel dan menurunkan tegangan permukaan. Saponin juga dapat mengganggu permukaan membran sel. Setyowati dkk. (2015) menyatakan alkaloid, terutama alkaloid steroid memiliki struktur sangat mirip dengan saponin yang digunakan sebagai bahan dasar sintesis hormon steroid untuk kontrasepsi oral. Alkaloid merupakan salah satu komponen pada biji pepaya yang diyakini memiliki sifat toksik terhadap ren sehingga dalam pemakaian produk herbal harus 
dipertimbangkan kandungan alkaloid tersebut (Kumala, 2006).

Berdasarkan pernyataan tersebut diduga senyawa antifertilitas menyebabkan gangguan struktur dan fungsi sel. Sel penyusun glomerulus diduga mengalami gangguan transport ion $\mathrm{Na}+$, $\mathrm{K}+$ dan ion-ion organik akibat paparan senyawa antifertilitas. Davey (2005) menjelaskan bahwa ren merupakan pengendali utama kalium, karena dalam ren terjadi sekresi kalium ke dalam cairan tubulus yang akan ditukar dengan ion natrium dan hidrogen serta proses regulasi $\mathrm{pH}$ urin. Hal tersebut berarti, jika sekresi kalium tersebut terganggu maka dapat menyebabkan kerusakan pada fisiologi ren. Guyton and Hall (2007) menjelaskan sel melakukan transport aktif ion $\mathrm{Na}+$ dan $\mathrm{K}+$ dengan menggunakan energi yang berasal dari metabolisme basal untuk mencapai kondisi muatan elektrolit yang setimbang. Sel tersebut tidak dapat memompa ion $\mathrm{Na}+$ keluar sel jika terjadi kerusakan sel. Ion $\mathrm{Na}+$ yang berlebihan dalam sel akan menyebabkan terjadinya perubahan morfologis sel yang disebut pembengkakan. Hal tersebut terjadi pada kelompok hewan yang diberi perlakuan bahan uji ekstrak air biji pepaya.

\section{Kesimpulan}

Berdasarkan penelitian yang telah dilakukan mengenai respon glomerulus ren mencit (Mus musculus) dengan perlakuan ekstrak air biji pepaya (Carica papaya) dan pil kontrasepsi dapat disimpulkan bahwa paparan ekstrak air biji pepaya selama 21 hari berpotensi menyebabkan kerusakan ren yang ditunjukkan dengan peningkatan ukuran diameter glomerulus.

\section{DAFTAR PUSTAKA}

Adeneye, A.A. and J.A. Olagunju, 2009. Preliminary hypoglycemic and hypolypidemic activities of the aqueous seeds extract of Carica papaya Linn, in Wistar Rat. Biology and Medicine 1(1): 110.

Akbar, B., 2010, Tumbuhan dengan Kandungan Senyawa Aktif yang Berpotensi Sebagai Bahan Antifertilitas. Jakarta: Adabia Press.
Astuti, Y. B., Zulkarnain dan S. Sundari. 2000. Penelitian Ekstrak Kayu Secang (Caesalpinia sappan L.) terhadap Motilitas Spermatozoa dan Laju Fertilitas Mus musculus L. Seminar Nasional Tumbuhan Obat Indonesia IX. Yogyakarta.

Bottger, Stefan., Hofmann, K., Melzig, Matthias F. 2012. Saponins can perturb biologic membranes and reduce the surface tension of aqueous solutions. Bioorganic \& Medicinal Chemistry. Volume 20: 28222828.

Davey, Patrick. 2005. At a Glance Medicine. Penerjemah: Annisa R. Terjemahan dari Medicine at a Glance. Erlangga. Jakarta.

Deaville, E.R., Givens , D.I. and Harvey, I.M. 2010. Chesnut and Mimosa Tannin Silages: Effect in Sheep Differ for Apparent Digestibility, Nitrogen Utilitation and Losses. Anim. Feed Sci. Technol. 157: 129138.

Dewi, Ayu. K., R. S. Ni Made dan S. Ni Made. 2013. Gambaran Mikroskopis Ginjal Tikus Putih (Rattus sp.) Jantan Dewasa setelah Pemberian Etanol Kronis. Jurnal Biologi, Vol.XVII (2): 33-36.

Francis G., Makkar H.P.S and Becker K. 2002. The Biological Action of Saponins in Animal Systems: A Review. British Journal of Nutrition. 88: 587-605.

Guyton, A.C. and J.E. Hall. 2007. Buku Ajar Fisiologi Kedokteran. EGC. Jakarta.

Ismarani. 2012. Potensi Senyawa Tannin dalam Menunjang Produksi Ramah Lingkungan. Jurnal Agribisnis dan Pengembangan Wilayah. 2 (3): 46-55.

Kristiana, E., 2011. Pengaruh Ekstrak Biji Pepaya Bangkok (Carica papaya Linn. Var Bangkok) terhadap Penurunan Fertilitas Mencit (Mus musculus) Strain BALB-C Betina. Skripsi. Pendidikan Biologi Jur. MIPA FKIP Universitas Jember.

Kumala, Sari Lusia Oktora. 2006. Pemanfaaatan Obat Tradisional dengan Pertimbangan Manfaat dan Keamanan. Majalah Ilmu Kefarmasian. 1(3). 
Kurnijasanti, Rochmah, Hamid, Iwan $\mathrm{S}$ dan Rahmaeati, Kadek. 2008. Efek Sitotoksik In Vitro dari Ekstrak Buah Makota Dewa (Phaleria machocarpa) terhadap Kultur Sel Kanker Mieloma. J. Penelit. Med. Eksakta. 1 (7): $48-54$

Manivannan, S., M. Balamurugan., K. Parthasarathi, G. Gunasekaran dan L. S. Ranganathan. 2009. Effect of vermicompost on soil fertility and crop productivity--beans (Phaseolus vulgaris). J. Environ. Biol. 30 (2):275-81.

Mardiati, S.M. dan A.J. Sitasiwi. 2016. Pertambahan berat badan mencit (Mus musculus L.) setelah perlakuan ekstrak air biji pepaya (Carica papaya Linn.) secara oral selama 21 hari. ejournal2.undip.ac.id.1(1): 1-6.

Naggayi, Madinah, M. Nozmo, I. Ezekiel, 2015. The Protective Effects of Aqueous Extract on Carica papaya seeds in Paracetamol Induced Nephrotoxicity in Male Wistar Rats. African Health Sciences. Vol. 15 Issue 2 .

Nurasri, Riani. 2016. Pengaruh Pemberian Virgin Coconut Oil (VCO) dan Olive Oil terhadap Mikroanatomi Ren Tikus Putih (Rattus norvegicus). Skripsi. Departemen Biologi, Fakultas Sains dan Matematika, Universitas Diponegoro. Semarang.

Price, S. A. and L. M. Wilson. 2006. Patofisiologi: Konsep Klinis Proses- Proses Penyakit, Edisi 6, Volume 1. EGC. Jakarta.

Punitha, N., Shettu, N dan Saravanan, R. 2015. Effect of Semi-Ripe Carica papaya Fruit Extracts on the Reproductive Structures in Female Albino Rats - An Histological Study. International Journal of Current Research in Life Sciences. Vol. 4 (6): 241245 ,

Raji, Y., A.O.Morakinyo, A.K. Oloyo, O.S.Akinsomisoye, Olufadekemi, T. KunleAlabi, P.R.C. Esegbue-Peters, F.O Awobajo, 2005. Impact of the Chloroform Extract of Carica papaya Seed on Oestrous cycle and Fertilityin Female Albino Rats. J.Med. Sci. 5(4): 337-343.
Rianita, S dan Melva, S. 2015. Pengaruh Ekstrak Etanol Daun Bangunbangun (Plectranthus amboinicus (Lour.) Spreng) Sebagai Preventif dan Kuratif Terhadap Efek Toksik Rhodamin B pada Histopatologi Ginjal Tikus Putih (Rattus norvegicus). Jurnal Biosains. 3 (1).

Santosa, Titih N., Saraswati, Tyas R. dan Tana, Silvana. 2011. Pengaruh Pemberian Diazepam, Formalin dan Minuman Beralkohol terhadap Bobot Intestinum, Hepar dan Ren Mencit (Mus musculus L.). Buletin Anatomi dan Fisiologi. 2 (19): 4254.

Setyowati, Widiastuti A. E., Sri Retno D. A., Ashadi., Bakti M dan Arif Hidayat. 2015. Aktivitas Antifertilitas Kontrasepsi dari Kulit Durian (Durio zibethinus Murr) Varietas Petruk. Seminar Nasional. Program Studi Pendidikan Kimia, Jurusan Pendidikan MIPA FKIP Universitas Sebelas Maret Surakarta.

Siburian, J., J.Marlina, A. Johari, 2008. Pengaruh Ekstrak Bii Pepaya (Carica papaya L.) pada Tahap Prakopulasi Terhadap Fungsi Reproduksi Mencit (Mus musculus L.) Swiss Webster Betina. Laporan Penelitian. PS Pendidikan Biologi Jurusan Pendidikan MPA FKIP Universitas Jambi.

Sitasiwi, Agung Janika dan Mardiati, Siti Muflikhatun. 2016. Efek Antifertilitas Ekstrak Air dari Biji Carica papaya terhadap Keteraturan Siklus Estrus Mencit (Mus musculus L.). Jurnal Anatomi dan Fisiologi. 1 (1): 68-74.

Soekmanto, A. 2003. Pengaruh Fraksi Aktif Tumbuhan Aglaia angustifolia terhadap Ginjal Mencit (Mus musculus). Natur Indonesia. 6(1):49-52.

Suhita, Ni Luh. P. R., W. Sudira., I. B. Winaya dan Oka. 2013. Histopatologi Ginjal Tikus Putih Akibat Pemberian Ekstrak Pegagan (Centella asiatica) Peroral. Buletin Veteriner Udayana. 2 (5).

Sukadana, I. M., S.R. Santi \& N. K. Juliarti. 2008. Aktivitas Antibakteri Senyawa Golongan Triterpenoid dari Biji Pepaya (Carica papaya L.). Jurnal Kimia, 2 (1) : 15-18. 
Uche-Nwachi E.O., C.V. Mitchell., and C. Mc

Ewen. 2011. Stereodogenic Enzyme Histochemistry in the Testis of Sprague Dawley Rats Following the Administration the Water Extracts from Carica Papaya Seed. Afr J Tradir Complement Altern Med. 8(1): 69-78.

Udoh, P., I. Essien, F. Udoh, 2005. Effects of Carica papaya (paw paw) seeds extract on the morphology of pituitary-gonadal axis of male Wistar rats. Phytotherapy Research. 19(12): 1065-1068.

Warisno. 2003. Budidaya Pepaya. Kanisius. Yogyakarta. 